\title{
The tectonometamorphic evolution of the Alpine metamorphic belt of the Central Pamir
}

\author{
MS Dufour†* and Yu V Miller‡ \\ † Geological Faculty, St. Petersburg State University, St.Petersburg, Universitetskaya nab. 7/9, 199034, RUSSIA \\ ¥ Institute of Precambrian Geology and Geochronology, Russian Academy of Science, St. Petersburg 199034, RUSSIA \\ *To whom correspondence should be addressed.E-mail: dufourms@rambler.ru
}

The Alpine fold zone of the Central Pamir forms an arc elongated in sublatitudinal direction between the Hercynians of the Northern Pamir and the Cimmerians of the Southern Pamir. Its structure was formed in Oligocene-Miocene as a result of the collision of continental masses of the Northern Pamir -Kunlun and the Southern Pamir-Karakoram after closing of the oceanic or suboceanic floor basin (Dufour 2000).

The Alpine zonal metamorphic belt of the kyanitesillimanite type (more correctly, of the intermediate type of the high pressure) including series of domes (thermal anticlines) can be traced along the Central Pamir. Cores of domes include migmatites and remobilized bodies of the Early Paleozoic gneisses and granites as the Kangmar dome in the Southern Tibet does. The sequence of endogenic processes forms tectonometamorphic cycle (Miller 1982, Miller and Dufour 2000) which includes two stages. Structural forms of the first stage are represented by parallel bedding flow or nappe structural parageneses, reflecting increase in temperature and decrease in viscosity of rocks. The second stage includes linear folding, systems of fractures and faults and other structures, reflecting gradual transition from plastic to brittle deformations in accordance with the decrease of temperature and increase of the rock viscosity. The correlation of metamorphic and metasomatic processes and the igneous activity with the sequentially generating structural forms provides a possibility to produce an unified scale of the development of endogenic processes.

1. The first stage of the tectonometamorphic cycle. Tectonic processes began with the formation of nappes and the displacement of masses of gabbros and pyroxenites. Then the rapid increase of the PT conditions till the maximum of $\mathrm{T}=\mathrm{ab}$. $700{ }^{\circ} \mathrm{C}, \mathrm{P}=7-7,5 \mathrm{kbar}$ was achieved. In central parts of thermal anticlines a parallel bedding schistosity $\mathrm{S}_{1}$ and locally small lying isoclinal folds $F_{1}$ were formed.

Processes of the high temperature metamorphism started resulting in formation of migmatites and small parallel bedded pegmatitic veins. These processes were followed by the $\mathrm{Na}$ metasomatism and attendant Fe-Mg metasomatism and then subtraction by leaching. The $\mathrm{S}_{1}$ schistosity was folded by small folds $F_{2}$. Then large to gigantic lying isoclinal folds $F_{3}$ with the amplitude of some $\mathrm{km}$ evolved. They deformed all deposits of the Central Pamir irrespective of the metamorphic degree. These folds have long normal limbs and short overturned limbs sheared by overthrusts. The $\mathrm{S}_{3}$ schistosity evolved parallel their axial planes. Large bodies of pegmatites occur in these slackening zones.

The front of metamorphism spread in the periphery of thermal anticlines after the formation of $\mathrm{F}_{3}$ folds. Therefore the $\mathrm{S}_{3}$ schistosity is the first one here. Thus the maximum metamorphic recrystallization at these places attributes to the end of the first stage or the beginning of the second stage of the tectonometamorphic cycle.

2. The second stage of the tectonometamorphic cycle. This stage is characterized by the gradual decrease of temperature and the drop of pressure till ab. 4 kbar. At this stage mainly large linear upright, sometimes overturned folds were superimposed on all earlier structures. NE striking $\mathrm{F}_{4}$ folds and NW strike $\mathrm{F}_{5}$ folds are recognized. The decompression caused the development of the andalusite-sillimanite type metamorphism and the formation of syenite and granite masses, miarolitic pegmatites and aplite veins. Systems of fractures and faults were generated as a result of the decrease of temperature and consequently of the rock plasticity. Late bodies of basic rocks were formed. The generation of systems of tectonic nappes and gravitational faults then continued after processes of metamorphism were ceased.

\section{References}

Dufour MS. 2000. The Central Pamir - an Alpine collision zone [abstract]. In: $15^{\text {th }}$ Himalaya-Karakoram-Tibet Workshop. Volume of abstracts. Beijing

MillerYV. 1982. Tectonometamorphic cycles (in Russian). Leningrad: Nauka. $160 \mathrm{p}$.

Miller YV and MS Dufour. 2000. Tectonometamorphic cycles in different geodynamic conditions. J China Univ Geosciences 11(4): 383-91 